\title{
Production of thermostable extracellular $\alpha$-amylase by a moderate thermophilic Bacillus licheniformis-AZ2 isolated from Qinarje Hot spring (Ardebil prov. of Iran)
}

\author{
ALI DELJOU1 \\ IMAN AREZI ${ }^{2 *}$ \\ ${ }^{1}$ Department of Agricultural Biotechnology, \\ Bu-Ali Sina University, Hamedan, Iran. \\ 2 Department of genomics, \\ Branch of Central Region of Iran, \\ Agricultural Biotechnology Research Institute of Iran \\ (ABRII), Isfahan, Iran

\section{* Correspondence:} \\ Mailing address: Iran, Isfahan-Najaf Abad Road, \\ Pajouhesh Blv. Agricultural Biotechnology Research \\ Institute of Iran (ABRII), \\ E-mail: iman.arezi@yahoo.com
}

Keywords: Bacillus licheniformis; Optimization; Basal medium; Agro-wastes, OFAT method.

List of nonstandard abbreviations: 16S rRNA: 16 S ribosomal RNA Agro-wastes: Agricultural-wastes DNS Reagent: 3,5- di nitro salicylic acid reagent LB medium: Luria-Bertani medium OFAT method: one-factor-at-a-time method PEG 4000: Polyethylene Glycol MW 4000 PEG 6000: Polyethylene Glycol MW 6000 RSM: $\quad$ Response surface method SDS: $\quad$ Sodium dodecyl sulfate

SmF: $\quad$ Submerged fermentation

SSF: $\quad$ Solid state fermentation

Received November 24, 2015.

Revised October 13, 2016.

Accepted November 17, 2016.

\begin{abstract}
Background and Purpose: Amylases are the most important enzymes that share about 30\% of the world enzyme market in food, animal feed, fermentation, textile and detergent industries. This study aimed at screening of some bacterial strains isolated from Qinarje Hot spring for amylolytic activity, and optimization of submerged fermentation conditions for maximum enzyme production by the higher $\alpha$-amylase producer.
\end{abstract}

Material and Methods: Among 3 bacterial strains, Bacillus licheniformis-AZ2 showed the highest amylolytic activity after starch hydrolysis test and Gram's iodine staining. Then, effect of some physicochemical and nutritional parameters were studied on bacterial growth and $\alpha$-amylase production using turbidimetric and DNS method, respectively. One-factorat-a-time method was followed to select the optimum level of each parameter. Partially purified extracellular enzyme from B. licheniformis-AZ2 was used to study the effects of $\mathrm{pH}$ and temperature on $\alpha$-amylase activity and stability.

Results: Compared to the basal medium, enzyme production increased 2.4 fold in optimized medium containing $1 \%(w / v)$ of tryptone (as a nitrogen source), $1 \%$ (w/v) of rice husk (as a carbon source), $0.3 \mathrm{~g} / \mathrm{L}$ of $\mathrm{CaCl}_{2}$ and $2 \%(w / v)$ of Tween 80 with $2 \%(v / v)$ inoculum after 84 hours of incubation at $40^{\circ} \mathrm{C}$ and $\mathrm{pH}$ 9.0. The partially purified enzyme showed maximum activity at $p H 7.0$ and $80^{\circ} \mathrm{C}$. It was also observed that $\alpha$-amylase is stable over a temperature range of $30^{\circ} \mathrm{C}$ to $80^{\circ} \mathrm{C}$ and $\mathrm{pH}$ of 6.0 to 10.0.

Conclusion: Our results show that $\mathrm{B}$. licheniformis- $A Z 2$ strain has an ability to produce the thermostable $\alpha$-amylase which could be suitable in starch processing and detergent industries.

\section{INTRODUCTION}

The enzymes belonging to amylase family ( $\alpha$-amylase, $\beta$-amylase and 1 glucoamylase) are very important due to their wide range of industrial applications such as food, fermentation, textile, paper and detergents. Though they can originated from plants, animals and microorganisms, fungal and bacterial amylases are mainly used for the industrial production, because of higher production rate, thermostability, less time and space for production and easier process modification and optimization (1-3). Alpha amylase (1,4- $\alpha-D$-glucan glucanohydrolase; E.C.3.2.1.1) is an enzyme that cleaves the $\alpha$-1,4-glucosidic linkages in starch, generating maltose and malto-oligosaccharides (4). A 

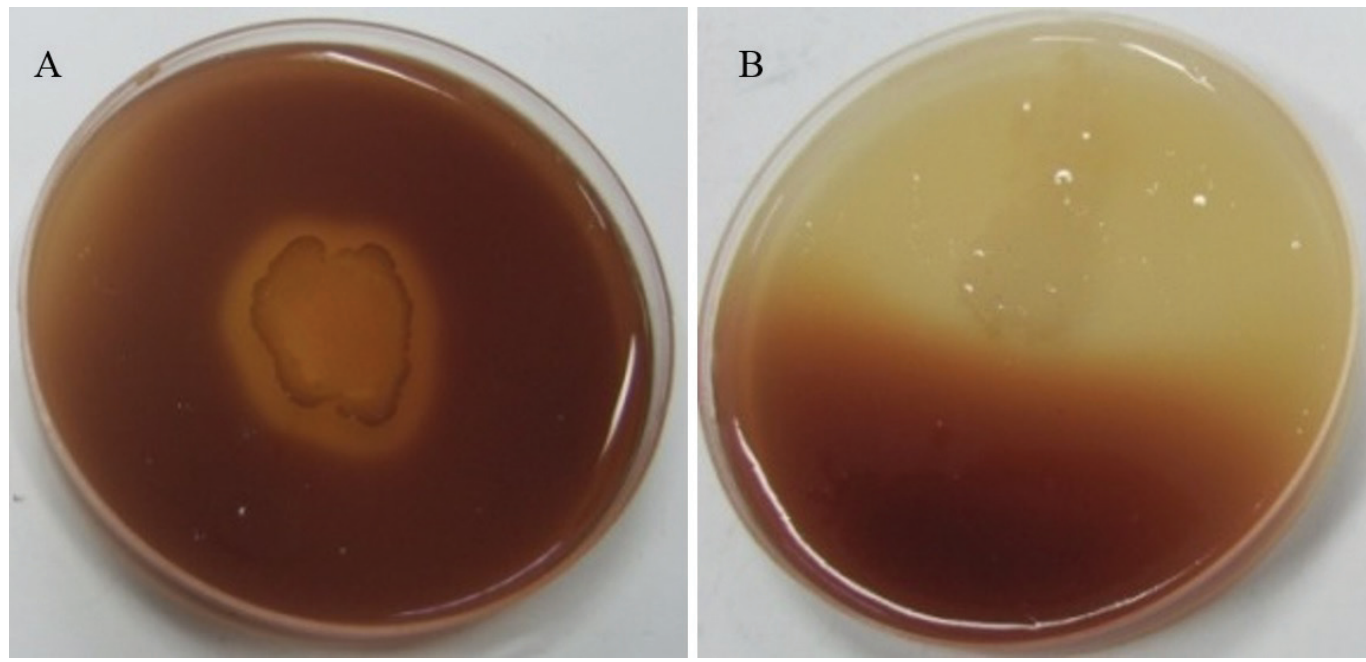

Figure 1. Detection of amylase activity after starch digestion by B. licheniforimis- $Q(A)$ and B. licheniformis-AZ2 (B). Starch agar plates were inoculated with bacterial spots and flooded with Gram's iodine solution after $24 \mathrm{~h}$.

significant increase in amylase production and utilization occurred in the early 1960s when the Bacillus subtilis $\alpha$ amylases and Aspergilus niger glucoamylases were used to replace acid catalysis in industrial production of dextrose from starch (5). Bacterial amylases are generally preferred to fungal amylases due to several characteristics and advantages they offers (1). Almost all members of the Bacillus genus can synthesize $\alpha$-amylase. Therefore, Bacillus spp. are considered to be the most important sources of $\alpha$-amylase and have been used extensively for this purpose (6). Despite similarities in the pattern of growth and the enzyme profiles of Bacillus spp., the optimized conditions for maximum enzyme production differ widely, depending upon strain (3). Thus, optimization of nutritional and physicochemical parameters is of utmost importance to perform the industrial process cost-effective and economically viable (7). The production of bacterial thermostable $\alpha$-amylases has been thoroughly investigated in submerged fermentation $(\mathrm{SmF})$ and solid state fermentation (SSF). However, because of the greater control of environmental factors and ease of handling, $\mathrm{SmF}$ is more common and is affected by a variety of physicochemical parameters such as composition of growth medium, inoculum age, $\mathrm{pH}$, temperature, nitrogen source and carbon source $(8,9)$. Enzyme production in fermentation process is usually measured by enzyme activity to determine the amount of enzyme present under defined conditions (10). OFAT approach (changing one-factor-at-atime) and keeping the others at a constant level is the main strategy used for selecting optimal operating condition. In spite of some limitations due to OFAT approach, it continues to be used widely in preliminary optimization studies to identify the most important parameters, and these limitations subsequently can be eliminated by employing response surface methodology (RSM) which is used to explain the combined effects of all the parameters in advanced studies $(11,12)$. Keeping all these facts in mind, in the present study three bacterial strains isolated from Qinarje Hot spring, were screened for amylase production through starch hydrolysis test. The strain showing maximal amylolytic activity was further optimized for $\alpha$-amylase production on fermentation with different nitrogen and carbon sources including other physicochemical parameters using OFAT method.

\section{MATERIALS AND METHODS}

\section{Chemicals and reagents}

The DNS reagent and dialysis tubing cellulose membrane were purchased from Sigma-Aldrich (USA). Potato soluble starch from Carl Roth (Germany); tryptone, peptone and bacteriological agar powder from HiMedia (India); sucrose, lactose, maltose and glucose from Scharlau (Spain) were also used in experiments. All other chemicals were purchased from Merck (Germany).

\section{Microorganisms}

The strains of Anoxybacillus contaminans-AZ1, B. licheniformis-Q and B. licheniformis-AZ2 used in the present study were obtained from Microbial Collection of Agricultural Biotechnology Department, at Bu-Ali Sina University, Hamedan, Iran. These strains have recently been isolated from Qinarje Hot springs (water sample of $82^{\circ} \mathrm{C}$ and $\mathrm{pH}$ 6.5) and identified based on $16 \mathrm{~S}$ rRNA gene sequence analysis.

\section{Screening of potent $\alpha$-amylase producing bacteria}

Bacterial strains were screened for amylolytic activity by starch hydrolysis test on starch agar plates [LB agar medium containing $1 \%(\mathrm{w} / \mathrm{v})$ potato starch at $\mathrm{pH}=7.0]$. The bacterial strains were spot inoculated on the starch 
agar plates and incubated at $40^{\circ} \mathrm{C}$ for $24 \mathrm{~h}$. After incubation, a $1 \%$ iodine solution $\left[2 \%(\mathrm{w} / \mathrm{v}) \mathrm{KI}+1 \%(\mathrm{w} / \mathrm{v}) \mathrm{I}_{2}\right]$ (freshly prepared) was flooded on the starch agar plate. Presence of blue reddish color around the colonies was considered as negative result and a clear zone of hydrolysis surrounding the colonies indicated as positive result (Figure 1). Each colony producing largest clear halo of hydrolysis was considered a potential $\alpha$-amylase producer. Such colony was selected for further investigations.

\section{Inoculum preparation}

The strain of B. licheniformis-AZ2 was streaked on LB agar plate and incubated for $24 \mathrm{~h}$ at $40^{\circ} \mathrm{C}$. Then, a loopful of freshly grown bacterial cells were transferred into $100 \mathrm{~mL}$ of LB liquid medium [tryptone $10 ; \mathrm{NaCl} \mathrm{10}$; yeast extract $5(\mathrm{~g} / \mathrm{L})]$ and incubated at $40^{\circ} \mathrm{C}$. Inoculum was taken from the early exponential phase of growth after $24 \mathrm{~h}$.

\section{Submerged fermentation for $\alpha$-amylase production}

$\alpha$-amylase production was carried out in $250 \mathrm{~mL} \mathrm{Er}$ lenmeyer flasks in $100 \mathrm{~mL}$ of basal medium consisting of $(\mathrm{g} / \mathrm{L})$ : starch 10 , yeast extract 3, peptone $5, \mathrm{NaCl} 3$, $\mathrm{MgSO}_{4} \cdot 7 \mathrm{H}_{2} \mathrm{O} 0.5(\mathrm{pH}=7)$. The aliquot of $1 \%(\mathrm{v} / \mathrm{v})$ of the total basal medium was taken as inoculum. The flasks were kept at $40^{\circ} \mathrm{C}$ on a rotary shaker at $120 \mathrm{rpm}$ for 120 $\mathrm{h}$. The $\alpha$-amylase production was determined by 3,5 -dinitrosalicylic acid method (13). At regular intervals (6 h), samples were harvested and the cell debries were removed by centrifugation $\left(10,000 \times \mathrm{g}\right.$ for $10 \mathrm{~min}$ at $\left.4^{\circ} \mathrm{C}\right)$ in a refrigerated centrifuge (Eppendorf 5810R, Germany). The cell-free supernatant was used for enzyme assay. In each series of experiments for optimization of basal medium $(\mathrm{BM}), \alpha$-amylase produced under such conditions served as a control.

\section{$\alpha$-amylase assay}

$\alpha$-amylase activity was determined by spectrophotometric method as described by Rick and Stegbauer (14). According to the procedure $\alpha$-amylase activity was assayed by adding $1 \mathrm{~mL}$ of enzyme (crude extract/fermented broth cell- free supernatant) to $1 \mathrm{~mL}$ of $1 \%(\mathrm{w} / \mathrm{v})$ soluble starch in $50 \mathrm{mM}$ Tris- $\mathrm{HCl}$ buffer $(\mathrm{pH}=7.0)$ in a test tube. The test tubes were covered and incubated for $5 \mathrm{~min}$ at $65^{\circ} \mathrm{C}$ in a water bath. Then $2 \mathrm{~mL}$ DNS reagent was added to each tube to stop the reaction and placed in boiling water bath exactly for $5 \mathrm{~min}$. After cooling the samples in a cold water bath, the absorbance was read at $540 \mathrm{~nm}$ in spectrophotometer (Varian CARY 100 UV-vis spectrophotometer, Australia). An $\alpha$-amylase activity unit was defined as the amount of $\alpha$-amylase required to catalyze the liberation of reducing sugar equivalent to one milligram of maltose per minute under the assay conditions.

\section{Optimization of the process parameters in submerged fermentation using OFAT method}

The basal medium was optimized with various factors influencing the $\alpha$-amylase production using OFAT methodology. The best choice in each experiment was used for the optimization of the next factor. Bacterial growth was also determined by measuring optical density of culture broth at $600 \mathrm{~nm}$ in each experiment.

\section{Optimization of physicochemical parameters}

The various physicochemical parameters of fermentation were optimized which included temperature, initial $\mathrm{pH}$, inoculum size and incubation time. Optimal temperature and $\mathrm{pH}$ were obtained by varying the temperature range from $10^{\circ} \mathrm{C}$ to $70^{\circ} \mathrm{C}$ and $\mathrm{pH}$ from 4.0 to 11.0 . The effect of inoculum size on $\alpha$-amylase production was also investigated by inoculating the basal medium with different concentrations of inoculum, from $1 \%$ to $7 \%$ $(\mathrm{v} / \mathrm{v})$. In addition, production of $\alpha$-amylase and bacterial growth were monitored during $120 \mathrm{~h}$ by taking samples every $6 \mathrm{~h}$ intervals at the optimal temperature, $\mathrm{pH}$ and inoculum size.

\section{Effect of nitrogen and carbon sources}

To investigate the effect of different nitrogen sources on $\alpha$-amylase production, peptone and yeast extract as the only nitrogen sources in the basal medium were replaced by different nitrogen sources such as tryptone, beef extract, yeast extract, peptone, ammonium hydrogen phosphate, sodium nitrate, potassium nitrate and urea at $1 \%(w / v)$ concentrations. Similarly, effect of various sugars and agricultral-wastes such as xylose, fructose, sucrose, glucose, lactose, sorbitol, myo inositol, mannitol, arabinose, wheat bran and rice husk at $1 \%(\mathrm{w} / \mathrm{v})$ concentrations were examined by replacing starch as the only carbon source in the basal medium.

\section{Effect of inorganic salts and surfactants}

Effect of different concentrations of inorganic salts such as $\mathrm{NaCl}(1$ to $9 \mathrm{~g} / \mathrm{L}), \mathrm{MgSO}_{4} \cdot 7 \mathrm{H}_{2} \mathrm{O}(0.5$ to $3 \mathrm{~g} / \mathrm{L})$, $\mathrm{K}_{2} \mathrm{HPO}_{4}(2$ to $8 \mathrm{~g} / \mathrm{L})$ and $\mathrm{CaCl}_{2}(0.1$ to $0.4 \mathrm{~g} / \mathrm{L})$ were investigated separately by replacing $\mathrm{NaCl}$ and $\mathrm{MgSO}_{4} \cdot 7 \mathrm{H}_{2} \mathrm{O}$ in the basal medium. Effect of various surfactants on $\alpha$-amylase production also were evaluated by adding SDS, PEG 4000, PEG 6000, Glycerol, Tween 80 and Triton X-100 at 2\% (w/v) into the finally optimized medium.

\section{Partial purification of enzyme}

$1 \mathrm{~L}$ of cell-free supernatant from optimized medium was fractionated into four fractions with ammonium sul- 
fate $(0-30 \%, 30-60 \%, 60-90 \%$ and $90-100 \%)$. Precipitated proteins were collected by centrifugation at 10,000 $\times \mathrm{g}$ for $10 \mathrm{~min}$ at $4^{\circ} \mathrm{C}$ and pellet obtained from each fraction was dissolved in $5 \mathrm{~mL}$ of $50 \mathrm{mM}$ Tris- $\mathrm{HCl}$ buffer $(\mathrm{pH}$ 7.0). Then, resuspended protein precipitates were dialysed overnight against $1 \mathrm{~L}$ (three changes) of the same buffer at $4^{\circ} \mathrm{C}$ with continuous stirring to completely remove ammonium sulfate. $\alpha$-amylase activity was measured in each fraction applying DNS method: $0.5 \mathrm{ml}$ of dialysed partially purified enzyme was added to $0.5 \mathrm{~mL}$ soluble starch $1 \%(\mathrm{w} / \mathrm{v})$ in $50 \mathrm{mM}$ Tris- $\mathrm{HCl}$ buffer ( $\mathrm{pH} 7.0)$ containing $5 \mathrm{mM} \mathrm{CaCl}_{2}$, test tubes were covered and incubated for $5 \mathrm{~min}$ at $65^{\circ} \mathrm{C}$ in a water bath. Then, $1 \mathrm{~mL}$ DNS reagent was added to each tube to stop the reaction and placed in boiling water bath for $5 \mathrm{~min}$, after cooling the samples in a cold water bath, the absorbance was read at $540 \mathrm{~nm}$.

\section{Effect of pH on $\alpha$-amylase activity and stability}

The effect of $\mathrm{pH}$ on $\alpha$-amylase activity of partially purified enzyme was evaluated by performing the $\alpha$-amylase assay in the following buffer systems: $50 \mathrm{mM}$ sodium acetate $(\mathrm{pH} 3.0-5.0), 50 \mathrm{mM}$ potassium phosphate $(\mathrm{pH}$ 6.0-7.0), $50 \mathrm{mM}$ Tris- $\mathrm{HCl}(\mathrm{pH} 8.0-9.0)$ and $50 \mathrm{mM}$ glycine- $\mathrm{NaOH}$ (pH 9.0-11.0). To study the influence of $\mathrm{pH}$ on the stability of $\alpha$-amylase, partially purified enzyme was mixed with the selected buffer systems at a ratio of $1: 2$ and incubated at $30^{\circ} \mathrm{C}$ for $24 \mathrm{~h}$, then the residual activity (\%) was determined under standard assay conditions.

\section{Effect of temperature on $\alpha$-amylase activity and stability}

To determine the optimum temperature, activity of the partially purified enzyme was measured at temperatures ranging from $30^{\circ} \mathrm{C}$ to $100^{\circ} \mathrm{C}$ for $5 \mathrm{~min}$ at $50 \mathrm{mM}$ Tris$\mathrm{HCl}$ buffer ( $\mathrm{pH}$ 7.0). For thermal stability, the partially purified enzyme was preincubated for $1 \mathrm{~h}$ at various temperatures $\left(30-100^{\circ} \mathrm{C}\right)$ before enzyme assay, and promptly cooled on ice and residual activity (\%) was determined under standard assay conditions.

\section{Statistical analysis}

All experiments were carried out in three replications based on a completely randomized design (CRD). Mean values and standard errors were calculated from the replications for each treatments. Statistical analysis was performed using SPSS V 16.0 software (SPSS inc. Polar Engineering and Consulting, USA) based on single factor analysis of variance (ANOVA). Duncan's multiple range test was used for mean comparison of the treatments at a $p$ value of 0.05 .

\section{RESULTS AND DISCUSSION}

\section{Isolation of $\alpha$-amylase producing bacteria}

Among 3 bacterial strains isolated from Qinarje Hot spring, two of them i.e, $Q$ and AZ2 hydrolysed starch on LB agar plate containing $1 \%(\mathrm{w} / \mathrm{v})$ potato starch at $\mathrm{pH}$

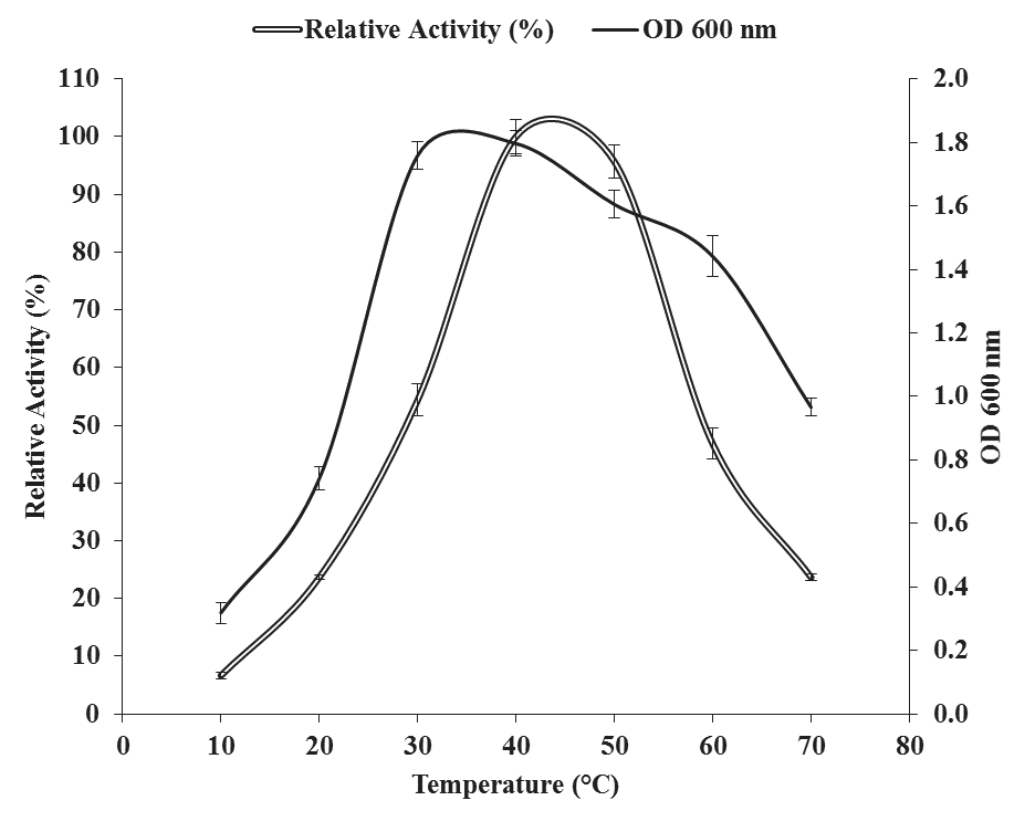

Figure 2. Effect of temperature on $\alpha$-amylase production and bacterial growth in basal medium, at $\mathrm{pH} 7.0$ and $1 \%$ (v/v) inoculum after $120 \mathrm{~h}$. Relative activity was defined as the percentage of maximal activity detected at standard assay conditions.

Mean \pm S.E.M $=$ Mean values \pm Standard error of means of three replications. 


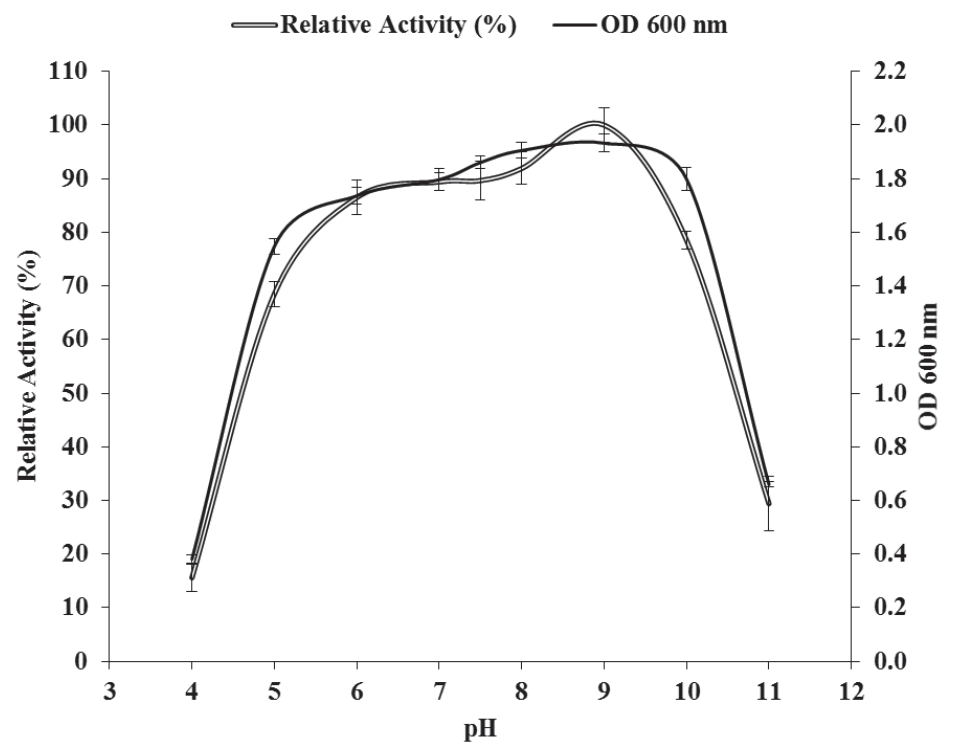

Figure 3. Effect of $\mathrm{pH}$ on $\alpha$-amylase production and bacterial growth in basal medium at optimal tempreture $40^{\circ} \mathrm{C}$ and $1 \%(v / v)$ inoculum after $120 \mathrm{~h}$.

Relative activity was defined as the percentage of maximal activity detected at standard assay conditions.

Mean \pm S.E.M Mean values \pm Standard error of means of three replications.

7.0 and $40^{\circ} \mathrm{C}$ (Figure 1). AZ2 strain produced a larger clear zone compared to the $\mathrm{Q}$ strain, which indicates higher amylolytic activity. Therefore it was selected for further studies on $\alpha$-amylase production. The higher $\alpha$ amylase production of strain AZ2 against strain $Q$ was also confirmed using DNS method in the LB liquid medium containing $1 \%(\mathrm{w} / \mathrm{v})$ potato starch at $\mathrm{pH} 7.0$ and $40^{\circ} \mathrm{C}$ (data not shown).

\section{Effect of temperature}

The bacterial growth and $\alpha$-amylase production were studied at different temperatures ranging from $10^{\circ} \mathrm{C}$ to $70^{\circ} \mathrm{C}$, at $\mathrm{pH} 7.0$ in basal medium with $1 \%(\mathrm{v} / \mathrm{v})$ inoculum after $120 \mathrm{~h}$. The bacteria could grow at all temperatures and enzyme synthesis occurred from $20^{\circ} \mathrm{C}$ to $70^{\circ} \mathrm{C}$. However, the maximal $\alpha$-amylase production in basal medium was observed at $40^{\circ} \mathrm{C}$ (Figure 2). Above the $50^{\circ} \mathrm{C}$ both, the growth and $\alpha$-amylase production, were decreased, indicates that the optimum temperature for maximal bacterial growth and $\alpha$-amylase production are similar. The influence of temperature on $\alpha$-amylase production is related to the growth of the organism. A wide range of temperature $\left(35-80^{\circ} \mathrm{C}\right)$ has been reported for optimal growth and $\alpha$-amylase production in Bacillus spp. (15). Konsula and Liakopoulou- Kyriakides reported that a thermophilic B. subtilis strain, isolated from fresh sheep's milk, produced maximal extracellular thermostable $\alpha$ amylase at $40^{\circ} \mathrm{C}$ in a medium containing low starch concentration (16). Furthermore, B. licheniformis-AZ2 shows similar optimal temperature $\left(40^{\circ} \mathrm{C}\right)$ for $\alpha$-amylase production and growth of B. licheniformis SPT27 (17), Bacillus sp. Marini (18), B. megaterium (5), B. licheniformis
BS1, B. licheniformis FS1, B. licheniformis GS1 (19) and B. subtilis GCBM-25 (4).

\section{Effect of $\mathrm{pH}$}

Enzyme synthesis and bacterial growth of $B$. licheniformis-AZ2 were studied at $\mathrm{pH}$ values from 4.0 to 11.0 in basal medium with $1 \%(\mathrm{v} / \mathrm{v})$ inoculum at $40^{\circ} \mathrm{C}$ after $120 \mathrm{~h}$. Optimal $\mathrm{pH}$ for $\alpha$-amylase production was found to be slightly alkaline at the $\mathrm{pH} 9.0$. As the $\mathrm{pH}$ was increased, a sudden decrease in bacterial growth and enzyme production was detected (Figure 3). No satisfactory growth rate was observed for the bacteria in the basal medium adjusted to $\mathrm{pH}$ below 5.0 and above 10.0. Among the physical parameters of the growth medium, $\mathrm{pH}$ plays an important role on enzyme secretion from the strain by inducing morphological changes such as cell size, cell shape, cell water content and cell complexity based on surface to volume ratio $(20,21)$. Enzymes are also affected by $\mathrm{pH}$. Changes in $\mathrm{pH}$ can lead to breaking of the ionic bonds that hold the tertiary structure of the enzyme in place and causes the enzyme to lose it's functional shape, particularly the shape of the active site. $\mathrm{pH}$ changes also shifts charges of the active-site amino acids leading to enzyme-substrate complex disruption (22). Most of the Bacillus strains used commercially for the production of $\alpha$-amylase, optimally grow and secrete $\alpha$ amylase at $\mathrm{pH}$ ranging from 6.0 to 9.0 (23). The $\mathrm{pH}$ range 5.0 to 9.0 was found to be optimal for $\alpha$-amylase production of our strain as previously reported for $B$. subtilis CM3 (24), B. licheniformis CUMC305 (25), B. thermooleovorans NP54 (26), B. subtilis AX20 (27) and B. licheniformis (28). 
잉 $600 \mathrm{~nm} \quad \mathrm{OU} / \mathrm{mL}$

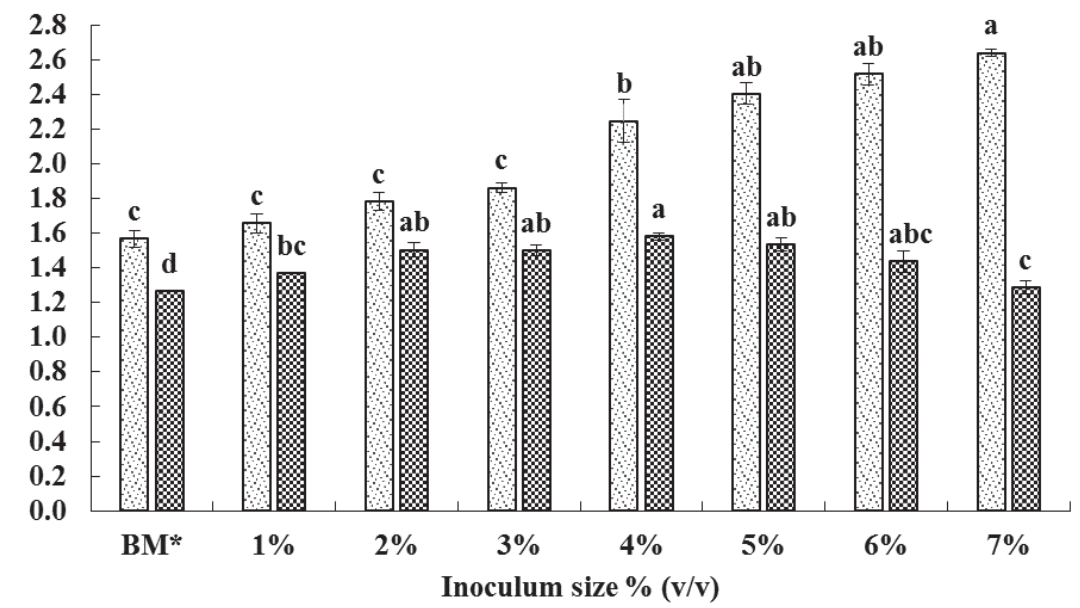

Figure 4. Effect of different inocula on $\alpha$-amylase production and bacterial growth in basal medium at pH 9.0 and temperature $40^{\circ} \mathrm{C}$ after $120 \mathrm{~h}$. Each letter denotes the mean of three replications and bar represents standard error. Means with different letters indicate significant differences between treatments $(P<0.05$, Duncan's multiple range test).

* Basal Medium (BM): a-amylase production and bacterial growth in basal medium at pH 7.0, temperature $40^{\circ} \mathrm{C}$ and $1 \%(v / v)$ inoculum after $120 \mathrm{~h}$.

\section{Effect of inoculum size}

The inoculum size plays an important role in the fermentation of enzymes (29). The different inocula, 1 to 7 $\%(\mathrm{v} / \mathrm{v})$ of basal medium at optimal $\mathrm{pH}$ and temperature were tested for the production of $\alpha$-amylase and bacterial growth (Figure 4 ). The production of $\alpha$-amylase was found to be optimal at $2 \%(\mathrm{v} / \mathrm{v})$ of the basal medium. As the inoculum size was further increased, we did not observe any significant increase in the production of $\alpha$ amylase. Decline in enzyme production at $7 \%(\mathrm{v} / \mathrm{v})$ of inoculum is likely due to the fact that at higher inocula, the bacteria grow rapidly, exhausting essential nutrients for growth at the initial stages that results in accumulation of other byproducts in the fermentation medium (4).

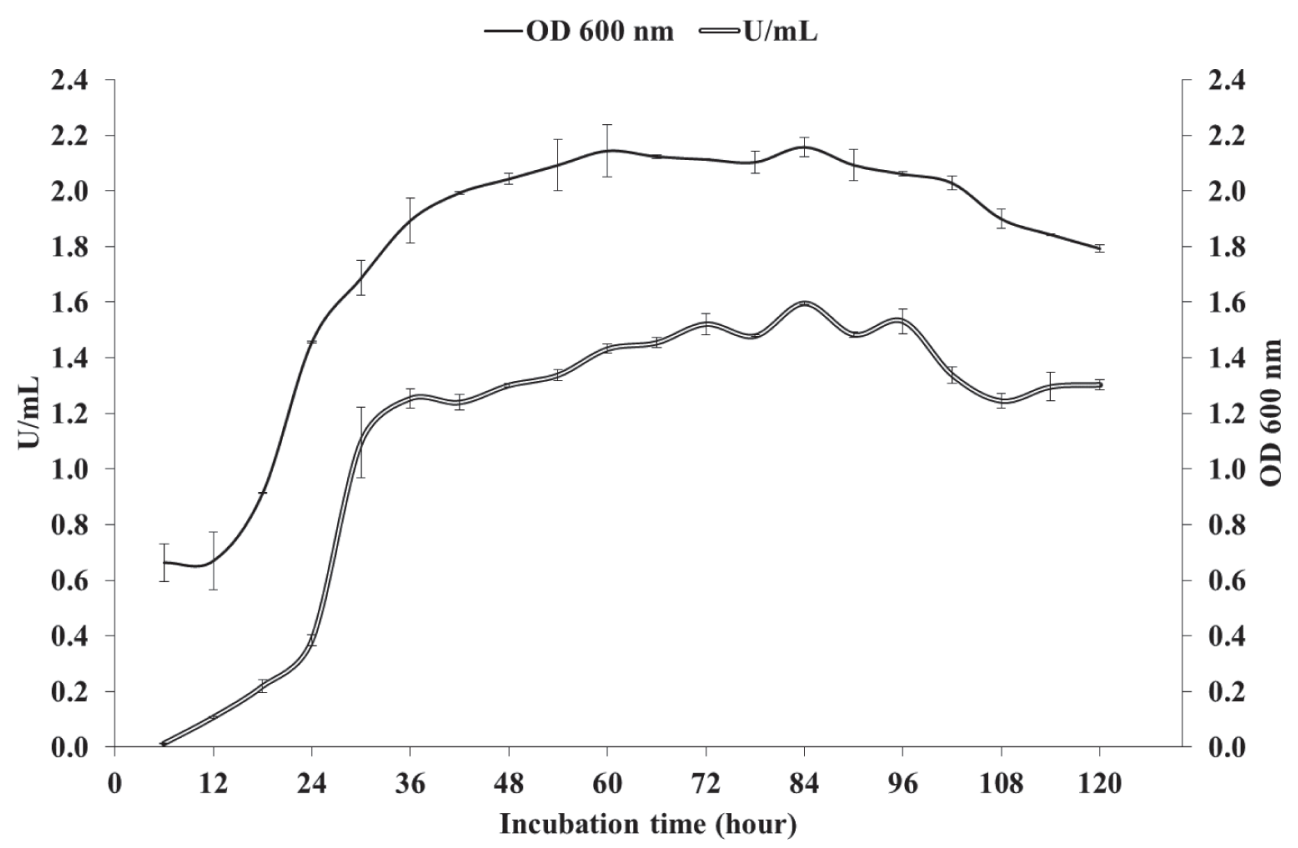

Figure 5. Effect of incubation time on $\alpha$-amylase production and bacterial growth in basal medium at optimal pH 9.0, temperature $40^{\circ} \mathrm{C}$ and $2 \%(v / v)$ inoculum.

Mean \pm S.E.M $=$ Mean values \pm Standard error of means of three replications. 
Our results are in good agreement with Dash et al. (30), for production of extracellular $\alpha$-amylase from $B$. subtilis-BI19.

\section{Effect of incubation time}

The production of $\alpha$-amylase and bacterial growth in basal medium with optimal cultural conditions i.e. $\mathrm{pH}$ 9.0, $40^{\circ} \mathrm{C}$ and $2 \%(\mathrm{v} / \mathrm{v})$ inoculum at different time courses are shown in Figure 5. Maximal $\alpha$-amylase production and bacterial growth were obtained after $84 \mathrm{~h}$ of incubation. After that bacterial growth and enzyme production gradually decreased. Optimal incubation time may vary in other Bacillus species. In the case of B. megaterium Aq-2007 (5), Bacillus sp. Strain KCPSS-12ss (2), B. licheniformis SPT27 (17) and B. lichenifromis Shahed-07 (23) maximal $\alpha$-amylase productions have been reported at 12, 24, 24 and $26 \mathrm{~h}$ of incubation, respectively. While $\alpha$-amylase production of B. subtilis JS-2004 was reported to be the highest at $48 \mathrm{~h}$ declining gradually up to $96 \mathrm{~h}$ (31). In some Bacillus strains the maximal $\alpha$-amylase production is reached in the exponential phase, whereas some other species achieve at the middle stationary phase (32). B. licheniformis-AZ2 produces the highest levels of $\alpha$-amylase when cell mass in shaking flasks enters the stationary phase of growth (Figure 5). It means that enzyme secretion in stationary phase is not growth associated and effective induction of $\alpha$-amylase may not occur until the stationary phase of growth has been reached and the readily available carbon sources were depleted from the fermentation medium (33).

\section{Effect of nitrogen source}

$\alpha$-amylase synthesis has been widely studied in the presence or absence of different nitrogen sources in several microorganisms (34). It has been correlated to the various amino acids and organic nitrogen sources like yeast extract, peptone and tryptone in the fermentation medium (23). $\alpha$-amylase production was investigated by replacing peptone and yeast extract in the basal medium with different organic and inorganic nitrogen sources at $1 \%(\mathrm{w} / \mathrm{v})$ concentration under optimal cultural conditions i.e. $\mathrm{pH} 9.0,40^{\circ} \mathrm{C}$ and $2 \%(\mathrm{v} / \mathrm{v})$ inoculum after $84 \mathrm{~h}$ of incubation (Figure 6). Among all organic nitrogen sources, tryptone showed the maximal enzyme production. Our result was similar to Iraj et al. (23). Maximal bacterial growth was also observed in the presence of organic nitrogen sources, particularly yeast extract. It has been found previously (35) that yeast extract can significantly reduce the lag phase promoting fast bacterial growth. Among inorganic nitrogen sources, $\mathrm{NH}_{4}{ }^{+}$and $\mathrm{NO}_{3}{ }^{-}$ions stimulated $\alpha$-amylase production, but urea showed inhibitory effect on both enzyme production and bacterial growth (Figure 6). Either positive $(5,17)$ or negative $(2$, $3,23)$ effect of inorganic nitrogen sources on $\alpha$-amylase production have been reported previously.

\section{Effect of carbon source}

The addition of carbon sources, either in the form of monosaccharides or polysaccharides could affect the en-

\section{ODD $600 \mathrm{~nm}$ 圆 $\mathrm{U} / \mathrm{mL}$}

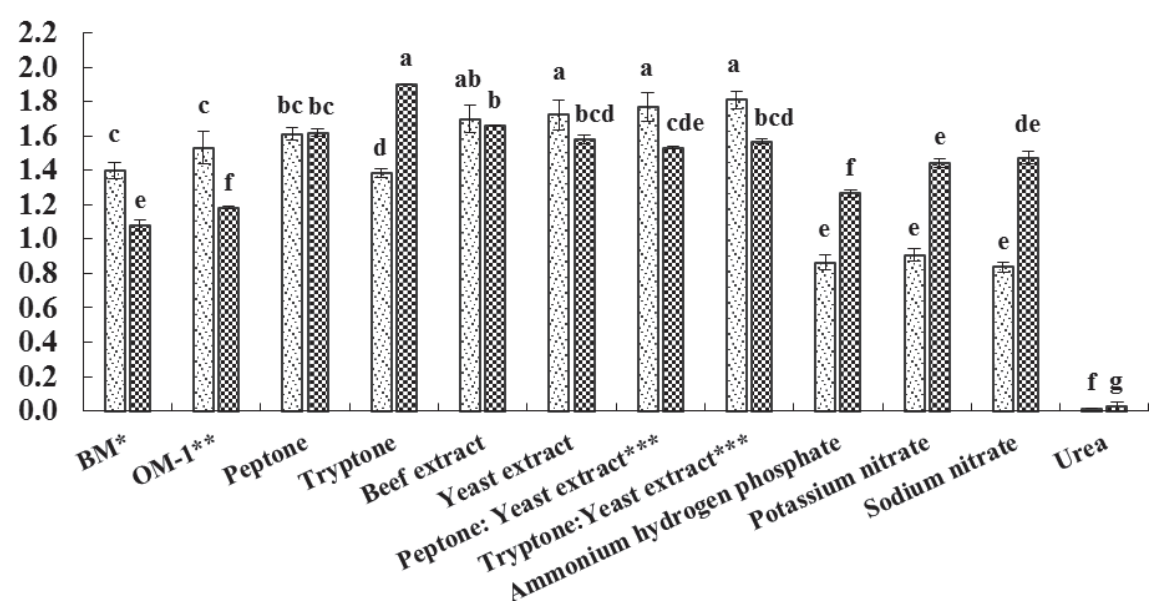

Figure 6. Effect of different nitrogen sources at $1 \%(w / v)$ on $\alpha$-amylase production and bacterial growth by replacement of peptone and yeast extract in the $1^{\text {st }}$ optimized medium.

Each letter denotes the mean of three replications and bar represents standard error. Means with different letters indicate significant differences between treatments $(P<0.05$, Duncan's multiple range test).

* Basal Medium (BM): a-amylase production and bacterial growth in basal medium at pH 7.0, temperature $40^{\circ} \mathrm{C}$ and $1 \%(v / v)$ inoculum after $120 \mathrm{~h}$.

** The $1^{\text {st }}$ Optimized Medium (OM-1): a-amylase production and bacterial growth in basal medium at optimal pH 9.0, temperature $40^{\circ} \mathrm{C}$ and $2 \%(v / v)$ inoculum after $84 \mathrm{~h}$.

*** Used at a ratio of (1:1) at a final concentration of $1 \%(w / v)$. 
⿴囗大 $600 \mathrm{~nm}$ \& $\mathrm{U} / \mathrm{mL}$

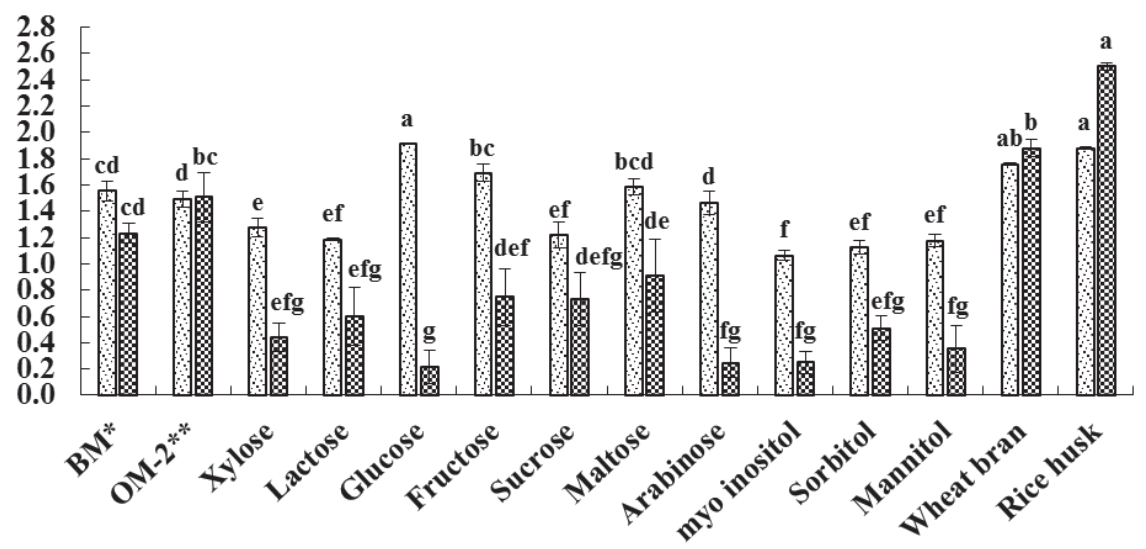

Figure 7. Effect of various carbon sources at $1 \%(w / v)$ on $\alpha$-amylase production and bacterial growth by replacing starch in the $2^{\text {nd }}$ optimized medium.

Each letter denotes the mean of three replications and bar represents standard error. Means with different letters indicate significant differences between treatments $(P<0.05$, Duncan's multiple range test).

* Basal Medium (BM): a-amylase production and bacterial growth in basal medium at pH 7.0, temperature $40^{\circ} \mathrm{C}$ and $1 \%(v / v)$ inoculum after $120 \mathrm{~h}$.

** The $2^{\text {nd }}$ Optimized Medium (OM-2): a-amylase production and bacterial growth in the presence of 1\% (w/v) tryptone, 1\% (w/v) starch, $\mathrm{NaCl} 3.0(\mathrm{~g} / \mathrm{L})$ and $\mathrm{MgSO}_{4} .7 \mathrm{H}_{2} \mathrm{O} 0.5(\mathrm{~g} / \mathrm{L})$ at optimal $\mathrm{pH} 9.0$, temperature $40^{\circ} \mathrm{C}$ and $2 \%(\mathrm{v} / \mathrm{v})$ inoculum after $84 \mathrm{~h}$.

zyme production (36). Agro-wastes also used as substrates for production of several enzymes either by solid state or submerged mode of fermentation to reduce the cost of fermentation media (37). The use of agro-wastes could be more effective, economic and help to solve environmental problems (38). However, effect of carbon source differ widely, depending on bacterial strains (39). Therefore, $\alpha$ amylase production was investigated by replacing starch in the basal medium with different sugars and agro-wastes at $1 \%(\mathrm{w} / \mathrm{v})$ concentration under optimal cultural conditions and nitrogen source [i.e. $\mathrm{pH} 9.0,40^{\circ} \mathrm{C}, 2 \%(\mathrm{v} / \mathrm{v})$ inoculum and $1 \%(\mathrm{w} / \mathrm{v})$ tryptone] after $84 \mathrm{~h}$ of incubation. Starch is a commonly accepted nutritional component for induction of amylolytic enzymes. This material was considered as a reference (2). Figure 7 shows that highest $\alpha$-amylase production was obtained in basal me-

이 $600 \mathrm{~nm} \otimes \mathrm{U} / \mathrm{mL}$

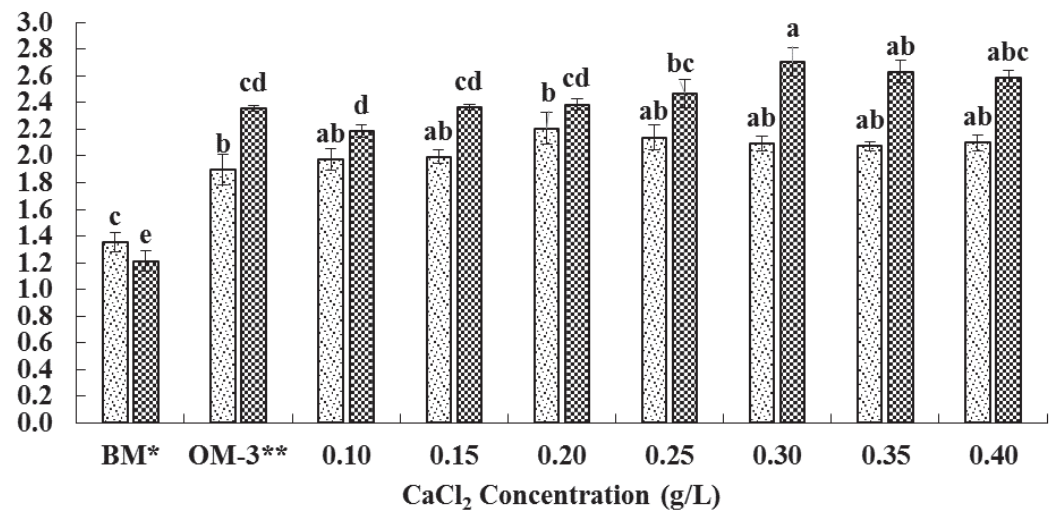

Figure 8. Effect of $\mathrm{CaCl}_{2}$ concentrations on $\alpha$-amylase production and bacterial growth by replacement of $\mathrm{NaCl}$ and $\mathrm{MgSO}_{4} .7 \mathrm{H}_{2} \mathrm{O}$ in the $3^{\text {rd }}$ optimized medium.

Each letter denotes the mean of three replications and bar represents standard error. Means with different letters indicate significant differences between treatments $(P<0.05$, Duncan's multiple range test $)$.

* Basal Medium (BM): a-amylase production and bacterial growth in basal medium at $p H$ 7.0, temperature $40^{\circ} \mathrm{C}$ and $1 \%(v / v)$ inoculum after $120 \mathrm{~h}$.

** The $3^{\text {rd }}$ Optimized Medium (OM-3): a-amylase production and bacterial growth in the presence of 1\% (w/v) tryptone, $1 \%(w / v)$ rice husk, $\mathrm{NaCl} 3.0(\mathrm{~g} / \mathrm{L})$ and $\mathrm{MgSO}_{4} .7 \mathrm{H}_{2} \mathrm{O} 0.5(\mathrm{~g} / \mathrm{L})$ at optimal $\mathrm{pH} 9.0$, temperature $40^{\circ} \mathrm{C}$ and $2 \%(\mathrm{v} / \mathrm{v})$ inoculum after $84 \mathrm{~h}$. 


\section{⿴囗OD $600 \mathrm{~nm} \otimes \mathrm{U} / \mathrm{mL}$}

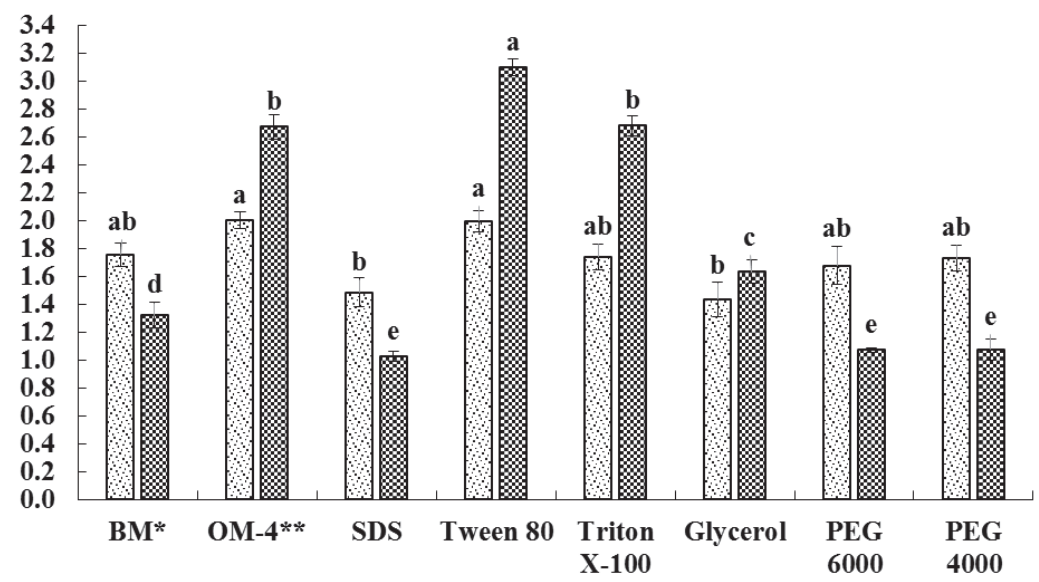

Figure 9. Effect of $2 \%(w / v)$ surfactants on on $\alpha$-amylase production and bacterial growth in the $4^{\text {th }}$ optimized medium.

Each letter denotes the mean of three replications and bar represents standard error. Means with different letters indicate significant differences between treatments $(P<0.05$, Duncan's multiple range test).

* Basal Medium (BM): a-amylase production and bacterial growth in basal medium at $p H$ 7.0, temperature $40^{\circ} \mathrm{C}$ and $1 \%(v / v)$ inoculum after $120 \mathrm{~h}$.

** The $4^{\text {th }}$ Optimized Medium (OM-4): a-amylase production and bacterial growth in the presence of 1\% (w/v) tryptone, 1\% (w/v) rice husk and $0.3(\mathrm{~g} / \mathrm{L}) \mathrm{CaCl}_{2}$ at optimal $\mathrm{pH} 9.0$, temperature $40^{\circ} \mathrm{C}$ and $2 \%(v / v)$ inoculum after $84 \mathrm{~h}$.

dium supplemented with rice husk followed by wheat bran. Other carbon sources reduced $\alpha$-amylase production compared to starch. Starch was used as a substrate for the production of $\alpha$-amylase from Bacillus sp., Bacillus spp. NCIB 11203 and IMD 370, B. subtilis (18). Although in some Bacillus spp. simple sugars such as lactose $(2,40)$, fructose $(5,17)$, glucose (41), dextrose (5) and maltose (18, 36 ) induced the highest $\alpha$-amylase production. However, it has also been demonstrated that in most species of genus Bacillus, the synthesis of carbohydrate degrading enzymes is subjected to catabolic repression by readily metabolisable substrates such as glucose and fructose (29). Results of our study showed that despite the higher cell density and bacterial growth rate in the presence of glucose in basal medium, highest enzyme production was obtained in the presence of rice husk (Figure 7). Our results are in agreement with reportsof Lin et al. (29) and Thippeswamy et al. (3) who demonstrated that $\alpha$-amylase synthesis is under catabolic repression by readily metabolisable substrates. Among different agro-wastes, wheat bran and rice husk have been used to maximal extent due to the presence of considerable amount of carbohydrates and nitrogen sources which stimulate the cells to express many hydrolytic enzymes $(37,38)$. Rice husk and wheat bran were also used as a low cost carbon substrates for $\alpha$-amylase production by $B$. subtilis (42).

\section{Effect of inorganic salts and surfactants}

Effect of inorganic salts at different concentrations was separately examined on $\alpha$-amylase production and bacterial growth by replacing $\mathrm{NaCl}$ and $\mathrm{MgSO} 4.7 \mathrm{H}_{2} \mathrm{O}$ in basal medium at optimal conditions obtained before optimization. Among different inorganic salts i.e. $\mathrm{NaCl}$, $\mathrm{MgSO}_{4} .7 \mathrm{H}_{2} \mathrm{O}, \mathrm{K}_{2} \mathrm{HPO}_{4}$ and $\mathrm{CaCl}_{2}$, only calcium chloride at $0.3 \mathrm{~g} / \mathrm{L}$ significantly increased the $\alpha$-amylase production (Figure 8), while other inorganic salts had no positive effect on $\alpha$-amylase production, moreover at higher concentrations (data not shown) a significant inhibition of bacterial growth and $\alpha$-amylase production was observed. The inhibitory effects of some inorganic salts may be related to the $\mathrm{pH}$ changes associated with their use in fermentation medium (43). Most of the $\alpha$ amylases are considered as metalloenzymeswhich require calcium ions $\left(\mathrm{Ca}^{2+}\right)$ for their activity, structural integrity and thermal stability (44). It has been predicted from the crystal structure of $\alpha$-amylase that calcium ion was involved in ionic interaction with charged residues like Asn 100, His 201 of domain A, and Asp 159 and Asp 167 of domain $B$ of $\alpha$-amylase. Active site of $\alpha$-amylase was located between domains $\mathrm{A}$ and $\mathrm{B}$ and calcium ion formed an ionic bridge between $A$ and $B$ domains of $\alpha$-amylase promoting its stability and catalytic activity (45). In the case of $B$. licheniformis previous studies suggested that $\alpha$-amylase production was enhanced due to the increasing availability of the calcium ion in the fermentation medium (8). Among all surfactants, addition of a non-ionic detergent, Tween 80 causes the maximal $\alpha$-amylase production (Figure 9). It has been demonstrated that addition of surfactants into fermentation medium can stimulate the release of extracellular enzymes by increasing cell membrane permeability (4). Surfactants contain fatty acids and silicates, and therefore can affect the enzyme secretion by decreasing surface tension and increasing the 
A

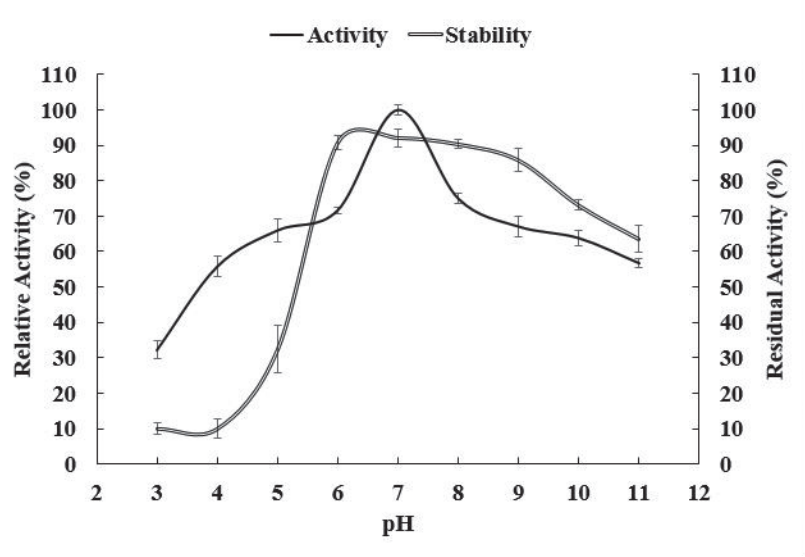

B

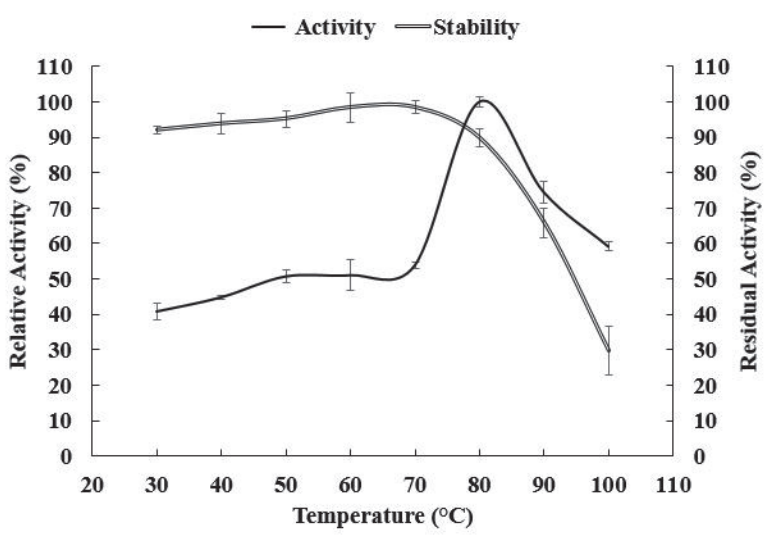

Figure 10. Effect of $p H(A)$ and temperature (B) on activity and stability of partially purified $\alpha$-amylase.

Relative activity was defined as the percentage of maximal activity detected in the standard assay conditions, while residual activity is expressed as a percentage of the original activity.

Mean \pm S.E.M $=$ Mean values \pm Standard error of means of three replications.

air supply of liquid medium (4). $\alpha$-amylase production seems to be greatly inhibited by the addition of sodium dodecyl sulfate (figure 9).

\section{Partial purification by ammonium sulfate precipitation}

Among different ammonium sulfate fractions, maximal $\alpha$-amylase activity was detected in the $60-90 \%$ fraction with a 6.6 fold purification and $54 \%$ yield after dialysis (data not shown). This partially purified fraction was used for the characterization studies on $\alpha$-amylase. Since the activity and thermal stability of $\alpha$-amylase at high temperatures were significantly enhanced in the presence of $5 \mathrm{mM} \mathrm{CaCl}_{2}$, all thermal and $\mathrm{pH}$ stability assays were performed in the presence of $\mathrm{Ca}^{2+}$ ions (data not shown).

\section{Effect of pH on amylase activity and stability}

Influence of $\mathrm{pH}$ on activity and stability of partially purified $\alpha$-amylase from $B$. licheniformis-AZ2 is presented in Figure 10. The optimal $\mathrm{pH}$ for $\alpha$-amylase activity was found to be at 7.0. The activity increased from $\mathrm{pH} 3.0$ and peaked at $\mathrm{pH} 7.0$, beyond which it gradually decreased until $\mathrm{pH}$ 11.0. The result of this study is in accordance with Iraj et al. who has reported that $B$. licheniformis Shahed-07 had an optimal activity at $\mathrm{pH} 7.0$ (23). The enzyme was also found relatively stable over the $\mathrm{pH}$ range 6.0 and 10.0 after $24 \mathrm{~h}$ of incubation at $30^{\circ} \mathrm{C}$ and retained more than $75 \%$ of it's original activity, while the maximal residual activity (about 92\%) was observed at $\mathrm{pH}$ 6.0-7.0. Stability of the enzyme at alkaline $\mathrm{pH}$ range indicates it's alkalitolerance. Comparable values for optimal $\mathrm{pH}$ and stability at high $\mathrm{pH}$ of Bacillus spp. have been reported by various researchers $(31,46,47)$.

\section{Effect of temperature on amylase activity and stability}

Thermostability is an important factor for the use of amylolytic enzymes in starch processing industries (23). The $\alpha$-amylase activity was assayed at different temperatures ranging from $30^{\circ} \mathrm{C}$ to $100^{\circ} \mathrm{C}$ at optimal $\mathrm{pH} 7.0$ under standard assay conditions (Figure 10). The optimal temperature for $\alpha$-amylase activity was found to be around $80^{\circ} \mathrm{C}$, the habitat temperature of the organism. The enzyme showed stability over a temperature range of $30^{\circ} \mathrm{C}$ to $80^{\circ} \mathrm{C}$ (more than $80 \%$ of the residual activity after $1 \mathrm{~h}$ of incubation). The stability of the enzyme could be due to the genetic adaptability to carry out it's biological activities at higher temperatures (48). Original activity of the enzyme was lost at $90^{\circ} \mathrm{C}$ and $100^{\circ} \mathrm{C}, 34 \%$ and $70 \%$, respectively. This might be due to loss of integrity of the enzyme structure as well as of it's original activity (49). Some other $\alpha$-amylases from thermophilic strains of $B$. licheniformis are reported to exhibit somewhat higher optimal temperature $\left(-90^{\circ} \mathrm{C}\right)$, but similar temperature stability to that obtained in our study $(25,50)$. Thermophilic $\alpha$-amylase from $B$. licheniformis-AZ2 seems to possess higher temperature optimum that the enzyme from moderately thermophilic $B$. subtilis (31) and the thermostable enzyme from Bacillus sp. TULH, isolated from a hot water spring (51).

\section{CONCLUSIONS}

Findings of this study show a 2.4 -fold increase in $\alpha$ amylase production by $B$. licheniformis-AZ2 strain in optimized medium containing $1 \%(\mathrm{w} / \mathrm{v})$ of tryptone, $1 \%$ (w/v) of rice husk, $0.3 \mathrm{~g} / \mathrm{L}$ of $\mathrm{CaCl}_{2}$ and $2 \%(\mathrm{w} / \mathrm{v})$ of Tween 80 with $2 \%(\mathrm{v} / \mathrm{v})$ inoculum after $84 \mathrm{~h}$ at $40^{\circ} \mathrm{C}$ and $\mathrm{pH} 9.0$ compared to the basal medium. Stability of the 
partially purified enzyme over a broad range of $\mathrm{pH}(6.0$ to 10.0$)$ and temperature $\left(30^{\circ} \mathrm{C}\right.$ to $\left.80^{\circ} \mathrm{C}\right)$ in the presence of $\mathrm{CaCl}_{2}$ implies that the produced calcium dependent thermostable $\alpha$-amylase has suitable characteristics for application in starch processing and other industries such as detergents. To be commercialized, further investigations are required for enhancement of the enzyme production.

Acknowledgments: This research was a part of the MSc thesis and authors greatly appreciate research facilities and financial support from Bu-Ali Sina University for conducting this research paper.

\section{REFERENCES}

1. PANDEY A, NIGAM P, SOCCOL C R, SOCCOL V T, SINGH D, MOHAN R 2000 Advances in microbial amylases. Biotechnol Appl Biochem 31: 135-152

2. SUMAN S, RAMESH K 2010 Production of a thermostable extracellular amylase from thermophilic Bacillus species. J Pharm Sci and Res 2: 149-154

3. THIPPESWAMY S, GIRIGOWDA K, MULIMANI V 2006 Isolation and identification of alpha-amylase producing Bacillus sp. from dhal industry waste. Ind J Biochem Biophys 43: 295-298

4. IKRAM-UL-HAQ N S, SHAMIM N, ASHRAF H, ALI S, QADEER M 2005 Effect of surfactants on the biosynthesis of alpha amylase by Bacillus subtilis GCBM-25. PakJ Bot 37: 373-379

5. AQEEL B M, UMAR D M 2008 Effect of alternative carbon and nitrogen sources on production of alpha-amylase by Bacillus megaterium. J Biotechnol 136: 293-302

https://doi.org/10.1016/j.jbiotec.2008.07.1864

6. PRETORIUS I, DE KOCK M, BRITZ T, POTGIETER H, LATEGAN P 1986 Numerical taxonomy of $\alpha$-amylase producing $B a$ cillus species. J Appl Bacteriol 60: 351-360 https://doi.org/10.1111/j.1365-2672.1986.tb01743.x

7. SINGH S K, SINGH S K, TRIPATHI V R, KHARE S K, GARG S K 2011 Comparative one-factor-at-a-time, response surface (statistical) and bench-scale bioreactor level optimization of thermoalkaline protease production from a psychrotrophic Pseudomonas putida SKG-1 isolate. Microb Cell Fact 10: 114-127 http://dx.doi.org/10.1016/j.procbio.2011.03.009

8. SOUZA P M D 2010 Application of microbial $\alpha$-amylase in industry-a review. Braz J Microbiol 41: 850-861

9. SATYANARAYANA T, RAO J L U M, EZHILVANNAN M 2005 Alpha amylases in Enzyme Technology. In Pandey A, Webb C, Soccol C R, Larroche C (Eds), Asiatech Publishers Inc., New Delhi, p 189-220

10. SCOPES R K 2002 Enzyme activity and assays. Encyclopedia of Life Sciences 1-6 https://doi.org/10.1038/npg.els.0000712

11. KHUSRO A, AARTI C 2015 Molecular identification of newly isolated Bacillus strains from poultry farm and optimization of process parameters for enhanced production of extracellular amylase using OFAT method. Res J Microbiol 10: 393-420 https://doi.org/10.3923/jm.2015.393.420

12. ELIBOL M 2004 Optimization of medium composition for actinorhodin production by Streptomyces coelicolor A3 (2) with response surface methodology. Process Biochem 39: 1057-1062 https://doi.org/10.1016/S0032-9592(03)00232-2

13. BERNFIELD P 1955 Amylase alpha and beta. In: Colowick S P, Kaplan N O (Eds), Methods Enzymol 1: 149-158
14. RICK W, STEGBAUER H $1974 \alpha$-amylase measurement of reducing groups. Meth Enzym Anal 2: 885-915. https://doi.org/10.1016/B978-0-12-091302-2.50074-8

15. BURHAN A, NISA U, GÖKHAN C, ÖMER C, ASHABIL A, OSMAN G 2003 Enzymatic properties of a novel thermostable, thermophilic, alkaline and chelator resistant amylase from an alkaliphilic Bacillus sp. isolate ANT-6. Process Biochem 38: 13971403. https://doi.org/10.1016/S0032-9592(03)00037-2

16. KONSULA Z, LIAKOPOULOU-KYRIAKIDES M $2004 \mathrm{Hy}-$ drolysis of starches by the action of an $\alpha$-amylase from Bacillus subtilis. Process Biochem 39: 1745-1749. https://doi.org/10.1016/j.procbio.2003.07.003

17. AIYER P D 2005 Effect of C:N ratio on alpha amylase production by Bacillus licheniformis SPT 27. Afr J Biotechnol 3: 519-522

18. ASHWINI K, GAURAV K, KARTHIK L, BHASKARA RAO K 2011 Optimization, production and partial purification of extracellular $\alpha$-amylase from Bacillus sp. marini. Arch Appl Sci Res 3: 33-42

19. VASEEKARAN S, BALAKUMAR S, ARASARATNAM V 2010 Isolation and identification of a bacterial strain producing thermostable $\alpha$-amylase. Trop Agric Res 22: 1-11

20. CERNA K, NEUSTUPA J 2010 The pH-related morphological variations of two acidophilic species of desmidiales (Viridiplantae) isolated from a lowland peat bog, Czech Republic. Aquat. Ecol. 44: 409-419 https://doi.org/10.1007/s10452-009-9296-x

21. RUDENKO S V 2010 Erythrocyte morphological states, phases, transitions and trajectories. Biochimica et Biophysica Acta (BBA)Biomembranes 1798: 1767-1778 https://doi.org/10.1016/j.bbamem.2010.05.010

22. RAZA S K 2011 Effect of pigment volume concentration on the enzyme activity of bioactive coatings. Master of Science in Engineering, Faculty of Technology and Science, Karlstads university p 66

23. IRAJ R, ASTANEH S D A, HOJJAT B, BARCHINI K A 2008 A thermostable amylase producing natural variant of Bacillus spp. isolated from soil in iran. Am J Agric Biol Sci 3: 591-596

24. SWAIN M R, KAR S, PADMAJA G, RAY R C 2006 Partial characterization and optimization of production of extracellular alpha-amylase from Bacillus subtilis isolated from culturable cow dung microflora. Pol J Microbiol 55: 289-296

25. KRISHNAN T, CHANDRA A 1983 Purification and characterization of $\alpha$-amylase from Bacillus licheniformis CUMS305. Appl Environ Microbiol 46: 430-437

26. MALHOTRA R, NOORWEZ S, SATYANARAYANA T 2000 Production and partial characterization of thermostable and calcium-independent $\alpha$-amylase of an extreme thermophile Bacillus thermooleovorans NP54. Lett Appl Microbiol 31: 378-384 https://doi.org/10.1046/j.1472-765x.2000.00830.x

27. NAJAFI M F, DEOBAGKAR D, DEOBAGKAR D 2005 Purification and characterization of an extracellular $\alpha$-amylase from Bacillus subtilis AX20. Protein Expr Purif41: 349-354 https://doi.org/10.1016/j.pep.2005.02.015

28. AHMED A A, IBRAHIM H M 2011 A potential new isolate for the production of a thermostable extracellular $\alpha$-amylase. J Bacteriol Res 3: 129-137

29. LIN L L, CHYAU C C, HSU W H 1998 Production and properties of a raw-starch-degrading amylase from the thermophilic and alkaliphilic Bacillus sp. Ts-23. Biotechnol Appl Biochem 28: 61-68

30. DASH B K, RAHMAN M M, SARKER P K 2015 Molecular identification of a newly isolated Bacillus subtilis BI19 and optimization of production conditions for enhanced production of extracellular amylase. BioMed Res Int 2015: 805-859 https://doi.org/10.1155/2015/859805 
31. ASGHER M, ASAD M J, RAHMAN S, LEGGE R 2007 A thermostable $\alpha$-amylase from a moderately thermophilic Bacillus subtilis strain for starch processing. J Food Eng 79: 950-955

32. HUANG H, RIDGWAY D, GU T, MOO-YOUNG M 2003 A segregated model for heterologous amylase production by Bacillus subtilis. Enzyme Microb Technol 32: 407-413 https://doi.org/10.1016/j.biortech.2013.12.031

33. WANDERLEY K J, TORRES F A, MORAES L M, ULHOA C $\mathrm{J} 2004$ Biochemical characterization of $\alpha$-amylase from the yeast Cryptococcus flavus. FEMS Microbiol Lett 231: 165-169 https://doi.org/10.1016/S0378-1097(03)00955-8

34. FORGATY W, KELLY C 1980 Amylase, amyloglucosidase and related gluconases. In: Rose A H (ed), Microbial enzymes and bioconversions economic microbiology. Academic Press, London 5: $115-170$

35. VAN HILLE R P, BROMFIELD L, BOTHA S, JONES G, VAN ZYL A, HARRISON S T 2009 The effect of nutrient supplementation on growth and leaching performance of bioleaching bacteria. Adv Mater Res 71: 413-416

36. GRATA K, NABRDALIK M, LATAŁA A 2010 Effect of different environmental factors on amylolytic activity of Bacillus cereus and Bacillus mycoides. Proceedings of ECOpole 4, Poland, p 49

37. SIVARAMAKRISHNAN S, GANGADHARAN D, NAMPOOTHIRI K M, SOCCOL C R, PANDEY A $2006 \alpha$-amylases from microbial sources-an overview on recent developments. Food Technol Biotechnol 44: 173-184

38. DIXIT S, NIGAM V K 2014 Microbial production of alkaline proteases using agricultural by-products. Int J Adv Res 2: 407-412

39. GRATA K, NABRDALIK M, LATAŁA A 2008 Effect of different carbon sources on amylolytic activity of Bacillus spp. isolated from natural environment. Proceedings of ECOpole 2, Poland, p 324

40. HAMILTON L M, KELLY C T, FOGARTY W M 1999 Purification and properties of the raw starch-degrading $\alpha$-amylase of Bacillus sp. IMD 434. Biotechnol Lett 21: 111-115 https://doi.org/10.1023/A:1005413816101

41. SALVA T, MORAES I 1995 Effect of the carbon source on alphaamylase production by Bacillus subtilis BA-04. Rev de Microbiol 26: $46-51$
42. BAYSAL Z, UYAR F, AYTEKIN Ç 2003 Solid state fermentation for production of $\alpha$-amylase by a thermotolerant Bacillus subtilis from Hot-spring water. Process Biochem 38: 1665-1668 https://doi.org/10.1016/S0032-9592(02)00150-4

43. AKCAN N 2011 High level production of extracellular $\alpha$-amylase from Bacillus licheniformis-ATCC 12759 in submerged fermentation. Rom Biotechnol Lett 16: 6833-6840

44. KADZIOLA A, ABE J, SVENSSON B, HASER R 1994 Crystal and molecular structure of barley $\alpha$-amylase. J Mol Biol. 239: 104121 https://doi.org/10.1006/jmbi.1994.1354

45. SAHA K, MAITY S, ROY S, PAHAN K, PATHAK R, MAJUMDAR S, GUPTA S 2014 Optimization of amylase production from B. amyloliquefaciens (MTCC 1270) using solid state fermentation. Int J Microb 2014: 1-7 https://doi.org/10.1155/2014/764046

46. DAHIYA P, RATHI B 2015 Characterization and application of alkaline $\alpha$-amylase from Bacillus licheniformis MTCC1483 as a detergent additive. Int Food Res J 22: 1293-1297

47. JOSHI BH 2011 A novel thermostable alkaline $\alpha$-amylase from Bacillus circulans PN5, biochemical characterization and production. Asi j Biotechnol 3: 58-67

48. MATHEW C, GUNATHILAKA R 2015 Production, purification and characterization of a thermostable alkaline serine protease from Bacillus lichniformis NMS-1. Int J Biotechnol Mol Biol Res 6: 19-27 https://doi.org/10.5897/IJBMBR2014.0199

49. El-BATAL A I, ELKENAWY N M, YASSIN A S, AMIN M A 2015 Laccase production by Pleurotus ostreatus and its application in synthesis of gold nanoparticles. Biotechnol Rep 5: 31-39. https://doi.org/10.1016/j.btre.2014.11.001

50. MORGAN F, PRIEST F 1981 Characterization of a thermostable $\alpha$-amylase from Bacillus licheniformis NCIB 6346.J Appl Bacteriol 50: 107-114 https://doi.org/10.1111/j.1365-2672.1981.tb00875.x

51. KAPADIA C, BIJAL G, NAFISHA P, ROHAN K, HARIHAR V 2013 Isolation, purification and characterization of thermostable Alpha-amylase enzyme from Bacillus sp. TULH. J Pure Appl Microb $7: 745-750$ 